\title{
Superficial acral fibromyxoma. Un uncommon tumor of the foot
}

\section{Fibromixoma acral superficial. Um tumor incomum do pé}

\author{
Santiago Pache ${ }^{1}$, Rodrigo Fratelli', Javier Cedrani², Paola Filomeno ${ }^{1}$, Thomas Clanton ${ }^{3,4}$ \\ 1. Instituto Nacional de Ortopedia y Traumatología (INOT), Universidad de la República, Montevideo, Uruguay. \\ 2. Hospital de Clínicas Dr. Manuel Quintela, Universidad de la República, Montevideo, Uruguay. \\ 3. Steadman Philippon Research Institute, Vail, Colorado, USA. \\ 4. The Steadman Clinic, Vail, Colorado, USA.
}

\section{ABSTRACT}

This study presents a case report of a 52-year-old female patient with a superficial acral fibromyxoma (SAF) of her left foot fifth toe. This is a very uncommon soft tissue tumor that affects mainly hands and feet, with a special predilection for toes, with the hallux most frequent. The tumor in this case was $3 \mathrm{~cm}$ long and $2.5 \mathrm{~cm}$ wide, which was unusually large. Few cases are larger than $2 \mathrm{~cm}$ long and localized on the fifth toe. The treatment was wide resection of the tumor through amputation of the fifth toe.

Level of Evidence V; Therapeutic Studies; Expert Opinion.

Keywords: Fibroma/surgery; Soft tissue neoplasms; Toes/surgery.

\section{RESUMO}

Este estudo apresenta um relato de caso de uma paciente de 52 anos com fibromixoma acral superficial (FAS) do quinto dedo do pé esquerdo. É um tumor de tecidos moles muito incomum que afeta principalmente mãos e pés, com uma predileção especial pelos dedos dos pés, sendo o hálux o mais frequente. $O$ tumor nesse caso tinha $3 \mathrm{~cm}$ de comprimento e $2,5 \mathrm{~cm}$ de largura, o que era particularmente grande. Poucos casos têm mais de $2 \mathrm{~cm}$ de comprimento e estão localizados no quinto dedo do pé. O tratamento foi ampla ressecção do tumor por amputação do quinto dedo do pé.

Nível de Evidência V; Estudos Terapêuticos; Opinião do Especialista.

Palavras-chave: Fibroma/cirurgia; Neoplasias de tecidos moles; Dedos dos pés/cirurgia.

How to cite this article: Pache S, Fratelli R, Cedrani J, Filomeno P, Clanton T. Superficial acral fibromyxoma. Un uncommon tumor of the foot. Sci J Foot Ankle. 2019;13(4):251-4.

\section{INTRODUCTION}

The superficial acral fibromyxoma (SAF) is a very uncommon soft tissue benign tumor. It is also known as digital fibromyxoma or cell digital fibroma ${ }^{(1)}$. It can occur at any age, typically involving fingers and toes, with particular predilection for the hallux ${ }^{(2)}$. It has a very slow growing pattern, with imaging studies showing soft tissue compromise with or without bone erosion. Given its recurrence potential and its location, treatment is surgical resection with wide margins ${ }^{(2)}$.

Study performed at the Instituto Nacional de Ortopedia y Traumatologia, Universidad de la República, Montevideo, Uruguay.

Correspondence: Santiago Pache. Av. Luis A. de Herrera, 11600, Montevideo, Uruguay. E-mail: santiagopache@hotmail.com Conflicts of interest: none. Source of funding: none.

Date received: August 26, 2019. Date accepted: December 17, 2019. Online: December 23, 2019.

\section{(c) (1)}




\section{CASE REPORT}

This study was approved by the Research Ethics Committee of our institution as well as the informed consent signed by the patient.

The patient was a 52-year-old obese female, without any other relevant history, who complained of a mass at the distal aspect of her left fifth toe. There was a two-year history, with a slow growing progression and slight pain. She related mild previous trauma to her foot 2 years before. On physical exam, she had a lobulated mass of approximately $3.5 \mathrm{~cm}$ diameter, which eliminated and deformed the nail region. The surface was wrinkled with firm consistency and defined limits (Figure $1 \mathrm{~A}$ and $\mathrm{B}$ ). The remainder of the physical examination was normal. Foot radiographs showed a soft tissue mass with slight bone erosion or scalloping at the distal phalanx region (Figure 1C). There were no signs of malignancy. Chest radiographs were normal. The MRI showed a $30 \mathrm{~mm}$ diameter mass on the dorsal aspect of the fifth toe, with lobulated borders. It showed medium intensity signal in $\mathrm{T} 2$ and $\mathrm{T} 1$, and a heterogeneous appearance with some hyperintense regions. The mass could be seen in contact with the cortex of the distal phalanx, which showed an irregular border (Figure 1D-F). Amputation of the fifth toe was performed with wide margin. The tumor was sent for pathological analysis (Figure 1G-I).

On the macroscopic analysis, a $30 \mathrm{~mm}$ diameter mass, with dermis and subcutaneous tissue compromise was observed. On microscopic analysis, it featured benign mesenchymal cell proliferation with a multinodular morphology of expansive growth. Each of these foci shows a myxoid matrix with thin collagen fibers, stellate cells without atypia, and slight vascularization. A good surgical margin was obtained from the entire tissue resected (Figure $2 A$ and $B$ ).
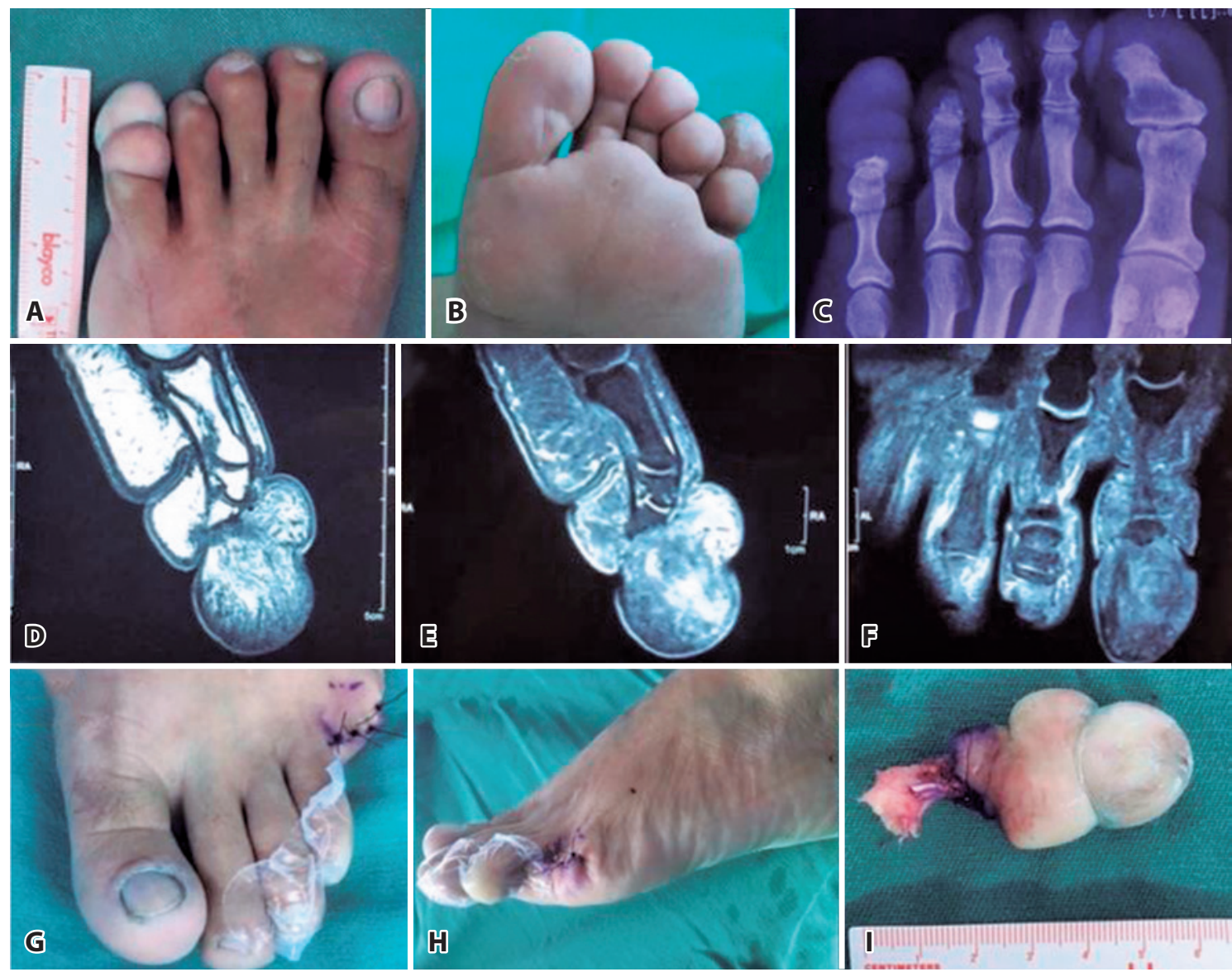

Figure 1. Clinical and radiological illustrations. A) Dorsal view. B) Plantar view. A $3.5 \mathrm{~cm}$ lobulated tumor that eliminates and deforms the nail region can be observed. C) Dorsal view x-ray. A soft tissue mass can be observed distal to the distal phalanx of the fifth toe. D) MRI:T1 sequence. Sagittal plane. E) MRI:T2 sequence. Sagittal plane. F) MRI:T2 sequence. Coronal plane. Medium signal is observed in every sequence with some hyperintense regions. $\mathrm{G}$ and $\mathrm{H}$ : Trans-proximal phalanx amputation of the fifth toe dorsal and lateral view. I) Resected tumor. 

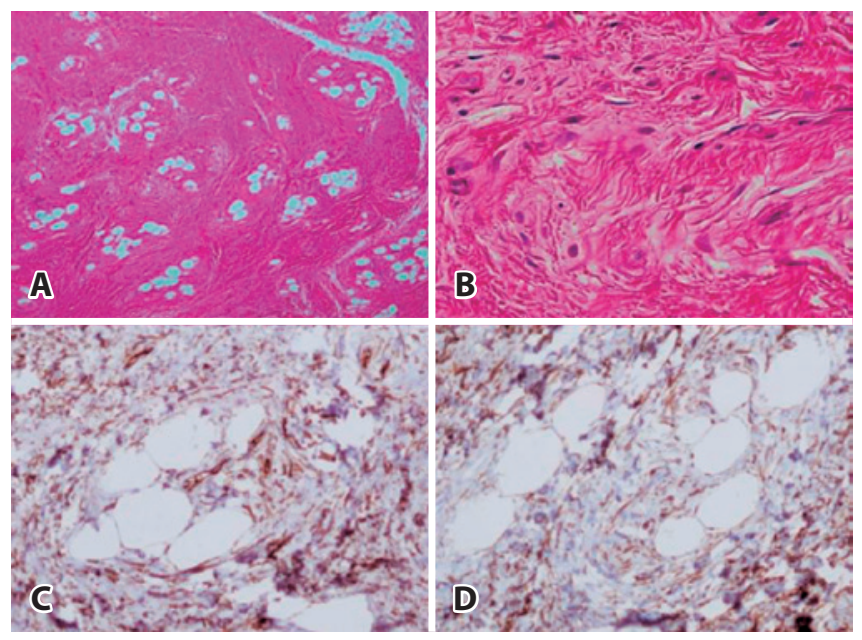

Figure 2. Histology. A) Hematoxylin and eosin 10X. Multinodular pattern is observed. B) Hematoxylin and eosin 40X. A myxoid matrix and low cell count is observed. C) CD34 positive expression (10x). D) CD10 positive expression (10x).

The immunohistochemistry (IHC) showed markedly positive reaction for CD34 and CD10 and negative for EMA. It also showed negative reaction for S100 Protein, Chromogranin, and Actin which ruled out Schwan cell tumor, glomus tumor, and a tumor of smooth muscle origin respectively (Figure $2 \mathrm{C}$ and $\mathrm{D}$ ). The clinical findings, location, imaging studies, morphology and IHC profile, confirmed a superficial acral fibromyxoma. At 14 months of follow-up, she has no pain, no signs of relapse and good functional outcome.

\section{DISCUSSION}

SAF was first described by Fetsch et al. ${ }^{(3)}$, in a retrospective study of 37 cases. It affects males and females with male predominance 2:1. It can occur at any age (range, 4-86 years), with an average age of 48 . It typically compromises the nail bed (subungual region) in more than $95 \%$ of cases according to Hollomann ${ }^{(2)}$. Less commonly, the tumor has been found in the palm and sole, the heel, or more rarely in the leg and thigh. The most frequent involvement site is the hallux ${ }^{(3,4)}$. SAF typically shows a chronic behavior, characterized by a slow growing mass with little or no pain at the distal aspect of a finger or toe. Nail deformation is common because of the nail bed compromise. Given the slow progression and the limited symptoms of this tumor, medical consultation is delayed in the majority of cases. In Fetsch's retrospective series, time from appearance to first medical consultation varied from 3 months to 30 years with an average of 3 years. Our case presented with a two years history. SAF has been described with varying shapes including unilocular and multilobulate. It seldom compromises mobility, and has little pain to palpation ${ }^{(3)}$.

On routine radiographs, SAF appears as a soft tissue mass with or without bone compromise. This could be scalloping or sclerosis of the underlying bone, which is present in more than $30 \%$ of cases $^{(2)}$. In contrast, our case showed a slight bone erosion at the distal aspect of the phalanx. On MRI, a hyperintense image could be observed on the T2 images. SAF typically appears as a solitary lesion growing mainly in dermal or subcutaneous tissue areas and less commonly reaching the deep fascia layer.

Histologically, it shows a spindle cell and stellate proliferation, enclosed in a myxoid or collagen matrix. Some regions may show a storiform pattern and blood vessels and stromal mast cells are often observed. Mitotic figures are usually sparse, averaging $<1$ per $10 \mathrm{HPF}^{(5)}$. SAF shows multinucleate cells in $50 \%$ of cases but with minimal nuclear atypia. Immunohistochemistry typically shows positive reaction to CD 34 in every case, while epithelial membrane antigen (EMA) and CD99 are positive in many cases. S100 protein, glial fibrillary acid protein (GFAP), actin, desmin and keratin are typically negative in the $\mathrm{SAF}^{(2,3)}$.

Given its rare appearance, SAF is often mistaken for other myxoid soft tissue tumors. The differential diagnoses can be classified into benign or malignant tumors. In the benign myxoid group, periungual fibroma and acquired digital fibrokeratoma are among the most common differential diagnoses. They typically extend into the dermis and have more cellularity on microscopy ${ }^{(6,7)}$. Neurofibroma can also be part of the differential diagnosis although it shows an $\mathrm{S} 100$ Protein expression. In the malignant myxoid group, dermatofibrosarcoma protuberans (DFSP), low-grade fibromyxoid sarcoma (LGFMS) and myxofibrosarcoma are the main differential diagnoses ${ }^{(8)}$. DFSP predominately presents on the trunk, with an extremely low incidence localized to the hands and feet, and it is negative for $E_{M A}{ }^{(2)}$. The LGFMS has a more aggressive behavior and disorganized cell growth pattern than SAF. It affects deeper structures and acral localization is uncommon ${ }^{(8)}$.

In his series of 37 patients with SAF, Fetsch et al. described two cases with significantly more focal atypia and a low mitotic rate, which suggested that these cases might become low-grade malignant neoplasms, although there was no evidence of an aggressive progression of these two tumors ${ }^{(3)}$. In order to reduce the risk of recurrence, which is low, a wide margin at the resection site is recommended ${ }^{(3)}$. In the study by Holloman et al., the recurrence 
rate was $24 \%$ with an average follow-up of 27 months. However, there were no recurrences in those cases with a free margin at the resection ${ }^{(2)}$.

We have a follow-up of this patient of 14 months with excellent clinical results. The clinical history and examination findings in this patient, together with the clear imaging studies, histology and IHC, provide a unique study of this rare soft tissue tumor. Localized to the fifth toe, and $3 \mathrm{~cm}$ long $\times 2 \mathrm{~cm}$ wide, this case was quite unusual in light of the less than 170 cases previously published in the literature ${ }^{(9)}$.

\section{CONCLUSION}

We have shown a case of a superficial acral fibromyxoma of the fifth toe of the left foot of a 52-year-old female patient. While this is an uncommon, benign, slow growing, soft tissue tumor, it has a predilection for fingers and toes as well as hands and feet. It should be part of the differential diagnosis of foot and toe tumors of myxoid origin. Surgery is the treatment of choice and normally curative with wide resection. There are no documented instances of metastases.

Author's contribution: Each author personally and significantly contributed towards the development of this article: SS *(https://orcid.org/0000-00034846-1087) wrote the article, participated in the review process, approved the final version; RF *(https://orcid.org/0000-0001-8027-1908) wrote the article, participated in the review process, approved the final version; JC (https://orcid.org/0000-0001-7581-3848) participated in the review process, approved the final version; PF *(https://orcid.org/0000-0003-4664-1527) conceived and planned the activities that led to the study, data collection, survey of medical records, performed the surgery, approved the final version; TC *(https://orcid.org/0000-0001-9831-7484) wrote the article, participated in the review process, approved the final version. ${ }^{*} \mathrm{ORCID}$ (Open Researcher and Contributor ID).

\section{REFERENCES}

1. Mine C, Support D. Chapter 12. Quality. 1982;(1969):224-50.

2. Hollmann TJ, Bovée JVMG, Fletcher CDM. Digital fibromyxoma (superficial acral fibromyxoma): a detailed characterization of 124 cases. Am J Surg Pathol. 2012;36(6):789-98.

3. Fetsch JF, Laskin WB, Miettinen M. Superficial acral fibromyxoma: A clinicopathologic and immunohistochemical analysis of 37 cases of a distinctive soft tissue tumor with a predilection for the fingers and toes. Hum Pathol. 2001;32(7):704-14.

4. Al-Daraji WI, Miettinen M. Superficial acral fibromyxoma: A clinicopathological analysis of 32 tumors including 4 in the heel. J Cutan Pathol. 2008;35(11):1020-6.
5. Jo VY, Fletcher CDM. WHO classification of soft tissue tumours: an update based on the 2013. 4th ed. Pathology. 2014;46(2):95-104.

6. Vinson RP, Angeloni VL. Acquired digital fibrokeratoma. Am Fam Physician. 1995;52(5):1365-7.

7. Ma D, Darling T, Moss J, Lee C-CR. Histologic variants of periungual fibromas in tuberous sclerosis complex. I Am Acad Dermatol. 2011;64(2):442-4

8. Sawaya $J \mathrm{~L}$, Khachemoune A. Superficial acral fibromyxoma. Int J Dermatol. 2015;54(5):499-508.

9. Wakabayashi Y, Nakai N, Takenaka H, Katoh N. Superficial acral fibromyxoma of the great toe: case report and mini-review of the literature. Acta Dermatovenerol Croat. 2012;20(4):263-6. 